\title{
Identifikasi Senyawa Bioaktif Alga Merah Halymenia durvillei (Identification Bioactive Compounds of Algae Halymenia durvillei)
}

\author{
Marina Flora Oktavine Singkoh ${ }^{\text {* }}$, Desy Maria Helena Mantiri al Cyska Lumenta ${ }^{2}$, \\ Henky Manoppo2 \\ 1) Program Studi Biologi FMIPA Universitas Sam Ratulangi, Manado 95115 \\ 2) Fakultas Perikanan dan IImu Kelautan Universitas Sam Ratulangi, Manado \\ *Email korespondensi: marinasingkoh16@gmail.com
}

Diterima 17 Februari 2019, diterima untuk dipublikasikan 28 Februari 2019

\begin{abstract}
Abstrak
Alga merah memiliki kemampuan untuk memproduksi metabolit sekunder yang bersifat sebagai senyawa bioaktif. Penelitian ini bertujuan untuk mengidentifikasi senyawa bioaktif pada alga merah Halymenia durvillaei. yang diambil dari pesisir Pantai Desa Rendingan, Kecamatan Tabukan Kepulauan Sangihe, Sulawesi Utara dengan metode skrining Fitokimia. Hasil penelitian menunjukan bahwa alga merah Halymenia durvillaei mengandung senyawa-senyawa bioaktif. Berdasarkan hasil penelitian skrining fitokimia dapat disimpulkan bahwa ekstrak etanol Halymenia durvillaei mengandung senyawa bioaktif alkaloid, fenol, saponin, tanin, dan steroid. Kata Kunci: Halymenia durvillaei, senyawa bioaktif, fitokimia
\end{abstract}

\begin{abstract}
Red algae have the ability to produce secondary metabolites that are bioactive compounds. This study aims to identify bioactive compounds in Halymenia durvillaei red algae taken from the coast of Rendingan Village Beach, Tabukan District, Sangihe Islands, North Sulawesi with the phytochemical screening method. The results showed that Halymenia durvillaei red algae contained bioactive alkaloid compounds. Based on the results of the phytochemical screening study it can be concluded that the Halymenia durvillaei ethanol extract contains bioactive alkaloid compounds, phenols, saponins, tannins, and steroids.

Keywords: Halymenia durvillaei, bioactive compounds, phytochemicals
\end{abstract}

\section{PENDAHULUAN}

Alga merah, alga coklat, dan alga hijau merupakan penghasil senyawa bioaktif yang potensial dan bermanfaat bagi pengembangan industri farmasi yang dapat dikelola sebagai antibakteri, antikanker, antitumor, atau sebagai reversal agen. Pada industri agrokimia dapat dikelola sebagai antifeedant, seperti herbisida, dan fungsida.

Kemampuan alga merah untuk memproduksi metabolit sekunder yang bersifat sebagai senyawa bioaktif dimungkinkan terjadi, karena kondisi lingkungan alga yang ekstrim seperti salinitas yang tinggi. Senyawa aktif biologis itu merupakan metabolit sekunder yang meliputi alkaloid, flavonoid, terpenoid, tannin, dan saponin. Kandungan senyawa metabolit sekunder dalam alga merah dapat diketahui dengan suatu metode pendekatan yang dapat memberikan informasi adanya senyawa metabolit sekunder. Salah satu yang dapat digunakan adalah metode uji fitokimia (Setyowati, dkk., 2014). 
METODE

Waktu dan Tempat Penelitian

Penelitian ini dilaksanakan pada bulan Oktober sampai Desember 2018. Pengambilan sampel di Pesisir Pantai Desa Rendingan, Kecamatan Tabukan Kepulauan Sangihe, Sulawesi Utara. Pembuatan ekstrak dan skrining fitokimia dilakukan di Laboratorium Fitokimia Jurusan Farmasi FMIPA UNSRAT.

\section{Alat dan Bahan}

Alat yang digunakan antara lain Laminar Air Flow (LAF) N-Biotek ${ }^{\circledR}$ Leading Biotechnology, Inkubator Incucell $^{\circledR}$, erlenmeyer Kimax $^{\circledR}$ USA $300 \mathrm{~mL}$ dan erlenmeyer Approx ${ }^{\circledR} 250$ $\mathrm{mL}$, tabung reaksi Iwaki TE-32 Pirex ${ }^{\circledR}$, cawan petri Pirex $^{\circledR}$, gelas ukur Iwaki CTE33 Asahi ${ }^{\circledR}$ Glass $50 \mathrm{~mL}$ dan 10 $\mathrm{mL}$, timbangan analitik $\mathrm{AE}-\mathrm{Adan}^{\circledR}$, ecopipette by CAPP $^{\circledR} 10-100 \mu \mathrm{L}, 20$ $200 \mu \mathrm{L}, 100-1000 \mu \mathrm{L}$, vacum tube Vaculab $^{\circledR} 3 \mathrm{~mL}$, autoklaf ALP $^{\circledR}$, sonicator Ultra ${ }^{\circledR} 8060 \mathrm{D}-\mathrm{H}$, hot plate Nesco LAB ${ }^{\circledR}$ MS-H280-Pro, beker glass Duran ${ }^{\circledR} 1000 \mathrm{~mL}$ dan $500 \mathrm{~mL}$, digital rotary evaporator STRIKE300 Steroglass ${ }^{\circledR}$, heating drying oven $\mathrm{DHG}^{\circledR}$ Model, vortex Benchmark ${ }^{\circledR}$, centrifuge Harmonic Series, lemari asam Christoper ${ }^{\circledR}$, Colony Counter, rak tabung, corong kaca, pipet tetes, lampu bunsen, jarum ose (loop), lemari pendingin, spektrofotometer UV-1800 Shimazu ${ }^{\circledR}$, toples kaca, gunting, spatula, dan blender.

Bahan-bahan yang digunakan yaitu Sampel segar Halymenia durvillaei, aluminium foil, kertas Whatman No. 1, kain kasa dan kapas steril, CMC, akuades steril, $\mathrm{NaCl}$ $0,9 \%, \mathrm{H}_{2} \mathrm{SO}_{4} 1 \%, \mathrm{BaCl} 1 \%$, kloroform, ammoniak, $\mathrm{H}_{2} \mathrm{SO}_{4}$ pekat, reagen Meyer, reagen Dragendorf, reagen Wagner, $\mathrm{FeCl}_{3} 1 \%$, serbuk Magnesium, $\mathrm{HCl}$ pekat, dan $\mathrm{CH}_{3} \mathrm{COOH}$ glasial.

\section{Pembuatan Ekstrak Halymenia durvillaei}

Ekstraksi adalah proses penarikan komponen aktif dari suatu campuran padatan dan/atau cairan dengan menggunakan pelarut tertentu. Proses ini merupakan langkah awal yang penting dalam penelitian tanaman obat, karena preparasi ekstrak kasar tanaman merupakan titik awal untuk isolasi dan pemurnian komponen kimia yang terdapat dalam tanaman (Mandal et al. 2007). Metode ekstraksi yang digunakan dalam penelitian adalah maserasi. Maserasi, yaitu proses penyaringan dengan merendam simplisia dalam pelarut yang sesuai pada temperatur ruangan dan terlindungi dari cahaya matahari yang disertai pengocokan atau pengadukan selama proses maserasi berlangsung (Ditjen POM, 2000).

Sampel segar $H$. durvillaeii dibersihkan dari substratnya dan dicuci hingga bersih. Sampel dipotong-potong kecil kemudian digerus. Sampel yang telah digerus selanjutnya direndam dalam pelarut etanol 95\% dengan perbandingan pelarut dan sampel yaitu 2:1 selama 24 jam kemudian maserat disaring menggunakan kertas Whatman no. 1 sehingga diperoleh filtrat pertama. Filtrat pertama disimpan di dalam botol sedangkan ampas sampel direndam kembali dengan pelarut dan perbandingan yang sama. Hal yang sama dilakukan pada maserasi ketiga selama 24 jam. Hasil maserasi yang telah disaring kemudian dikumpulkan dan diuapkan dengan menggunakan alat rotary vacum evaporator pada suhu $45^{\circ} \mathrm{C}$ agar terbentuk ekstrak kental. Hasil ekstrak kental ini merupakan ekstrak dengan konsentrasi $100 \%$ dan untuk mencegah kehilangan senyawasenyawa yang terkandung dalam ekstrak, ekstrak harus disimpan pada suhu $18^{\circ} \mathrm{C}$. 


\section{Skrining Fitokimia Ekstrak Halymenia durvillaei \\ Skrining fitokimia ekstrak $H$. durvillaei meliputi pemeriksaan senyawa golongan alkaloid, flavonoid, tanin, terpenoid/steroid dan saponin. Metode analisis yang digunakan berdasarkan pada Harborne (1987).}

\section{Pemeriksaan Alkaloid}

Sebanyak empat gram ekstrak ditambahkan kloroform secukupnya, selanjutnya ditambahkan $10 \mathrm{~mL}$ amoniak $10 \%$ dalam kloroform. Larutan kemudian disaring menggunakan kertas saring. Filtrat dimasukkan ke dalam erlenmeyer kemudian ditambahkan 10 tetes $\mathrm{H}_{2} \mathrm{SO}_{4} 2 \mathrm{M}$. Campuran dihomogenkan dengan teratur, dibiarkan beberapa menit hingga terbentuk dua lapisan. Lapisan diatas dipindahkan pada tiga tabung reaksi, masing-masing 2,5 mL. Ketiga larutan diuji dengan pereaksi Meyer, Dragendorf, dan Wagner. Apabila terbentuk endapan menunjukkan bahwa sampel tersebut positif mengandung alkaloid, dengan pereaksi Meyer memberikan endapan berwarna putih, dengan pereaksi Dragendorf memberikan endapan berwarna merah jingga dan dengan pereaksi Wagner memberikan endapan berwarna coklat.

\section{Pemeriksaan Saponin}

Sebanyak $50 \mathrm{mg}$ ekstrak ditambahkan $10 \mathrm{~mL}$ air sambil ditambahkan $1 \mathrm{~mL} \mathrm{HCl}$ pekat dan dikocok kuat. Apabila busa yang terbentuk tetap stabil selama kurang lebih 15 menit, maka ekstrak positif mengandung saponin (Darwis, 2000).

\section{Pemeriksaan Steroid/Triterpenoid}

Sebanyak $50 \mathrm{mg}$ ekstrak ditambahkan $\mathrm{CH}_{3} \mathrm{COOH}$ glasial sebanyak 10 tetes dan 2 tetes $\mathrm{H}_{2} \mathrm{SO}_{4}$ pekat. Larutan dikocok perlahan dan biarkan selama beberapa menit. Positif steroid akan memberikan warna biru atau hijau, sedangkan triterpenoid akan memberikan warna merah atau ungu (Nohong, 2009).

\section{Pemeriksaan Tanin}

Sebanyak $50 \mathrm{mg}$ ekstrak ditambahkan $1 \mathrm{~mL}$ larutan $\mathrm{FeCl}_{3} 10 \%$. Adanya tanin ditunjukkan dengan terbentuknya warna biru tua atau hitam kehijauan (Robinson, 1991)

\section{Pemeriksaan Flavonoid}

Sebanyak $50 \mathrm{mg}$ ekstrak ditambahkan $100 \mathrm{~mL}$ air panas, didihkan selama 5 menit kemudian disaring menggunakan kertas saring. Filtrat sebanyak $2 \mathrm{~mL}$ ditambahkan 0,05 gram serbuk Magnesium (Mg) dan $1 \mathrm{~mL} \mathrm{HCl}$ pekat, kemudian dikocok kuat. Uji positif ditunjukkan dengan terbentuknya warna merah, kuning atau jingga (Sutisna, 2000).

\section{HASIL DAN PEMBAHASAN}

Metode ekstraksi yang digunakan adalah metode maserasi. Cara ini merupakan metode yang mudah dilakukan dan menggunakan alat-alat sederhana, cukup dengan merendam sampel dalam pelarut. Pelarut yang digunakan adalah etanol. Pelarut ini dapat melarutkan hampir semua senyawa organik yang ada pada sampel, baik senyawa polar maupun non polar. Etanol mudah menguap, sehingga mudah dibebaskan dari ekstrak. Semua filtrat yang diperoleh dari hasil ekstraksi diuapkan menggunakan rotary evaporator sehingga diperoleh ekstrak kasar (crude extract). Ekstrak yang digunakan pada skrining fitokimia merupakan ekstrak dengan konsentrasi $100 \%$, karena itu tidak dilakukan pengenceran terhadap ekstrak yang akan digunakan.

Hasil skrining fitokimia ekstrak etanol Halymenia durvillaei yang dianalisis keberadaan senyawa bioaktifnya meliputi uji alkaloid, flavonoid, tanin, steroid dan terpenoid (Tabel 1). 
Tabel 1. Hasil skrining fitokimia ekstrak Halymenia durvillaei

\begin{tabular}{|c|c|c|c|}
\hline Skrining Fitokimia & $\begin{array}{l}\text { Hasil Positif } \\
\text { (Pustaka) }\end{array}$ & Hasil Uji & Kesimpulan \\
\hline $\begin{array}{l}\text { Alkaloid Reagen } \\
\text { Dragendorf }\end{array}$ & $\begin{array}{l}\text { Endapan Merah } \\
\text { Jingga }\end{array}$ & Jingga & Positif \\
\hline $\begin{array}{l}\text { Alkaloid Reagen } \\
\text { Wagner }\end{array}$ & $\begin{array}{l}\text { Endapan Merah } \\
\text { Coklat }\end{array}$ & Kecoklatan & Positif \\
\hline $\begin{array}{l}\text { Alkaloid Reagen } \\
\text { Mayer }\end{array}$ & Endapan Putih & Bening & Positif \\
\hline Steroid & $\begin{array}{l}\text { Warna Biru } \\
\text { Kehijauan }\end{array}$ & --- & Negatif \\
\hline Triterpenoid & $\begin{array}{l}\text { Warna Merah atau } \\
\text { Ungu }\end{array}$ & Merah & Positif \\
\hline Saponin & Buih/Busa Stabil & Buih Stabil & Positif \\
\hline Tanin & $\begin{array}{l}\text { Warna Biru Tua } \\
\text { atau Hitam } \\
\text { Kehijauan }\end{array}$ & Hijau & Positif \\
\hline Flavonoid & $\begin{array}{l}\text { Merah Tua,Kuning } \\
\text { atau Jingga }\end{array}$ & Merah Tua & Positif \\
\hline
\end{tabular}

Pemeriksaan Kualitatif Senyawa Alkaloid

Hasil yang diperoleh dari pengujian senyawa alkaloid ekstrak etanol Halymenia durvillaei pada reagen Dragendorf terbentuk endapan berwarna jingga yang menunjukkan hasil positif, pada reagen Wagner terbentuk endapan berwarna cokelat yang menunjukkan hasil positif, dan pada reagen Mayer hasil endapan berwarna putih yang menunjukkan hasil positif mengandung senyawa alkaloid. Hasil diatas dapat disimpulkan bahwa ekstrak etanol $H$. durvillaei positif mengandung alkaloid. Prinsip dari metode ini adalah reaksi pengendapan yang terjadi karena adanya penggantian ligan. Menurut Sastroamidjojo (1996), metode ini memiliki kelemahan yaitu reagenreagen tersebut tidak saja dapat mengendapkan alkaloid tetapi juga dapat mengendapkan beberapa jenis senyawa antara lain, protein, kumarin, alfa piron, hidroksi flavon, dan tanin. Reaksi tersebut dikenal dengan istilah false positive. Hasil pemeriksaan kualitatif alkaloid ekstrak etanol $H$. durvillaei terdapat pada Gambar 1.
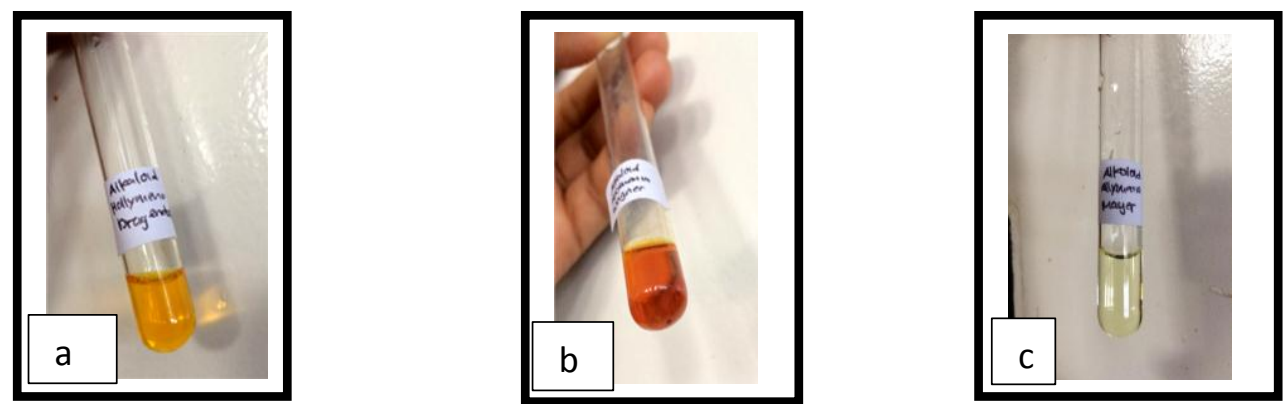

Gambar 1. Hasil pemeriksaan kualitatif Alkaloid : a. reagen Dragendorf b. reagen Wagner dan c. reagen Meyer (c) 


\section{Pemeriksaan Kualitatif Senyawa Steroid dan Triterpenoid}

Hasil yang diperoleh dari pemeriksaan kualitatif senyawa steroid dan triterpenoid menunjukkan bahwa ekstrak etanol $H$. durvillaei positif mengandung triterpenoid yang ditandai dengan terbentuknya warna merah saat ditambahkan asam asetat glasial pada ekstrak masing-masing enam tetes dipindahkan kedalam tiga tabung reaksi dan ditambahkan dua sampai tiga tetes asam sulfat pekat. Berdasarkan teori/pustaka suatu ekstrak positif mengandung triterpenoid jika ekstrak ditambahkan $\mathrm{CH}_{3} \mathrm{COOH}$ glasial dan beberapa tetes $\mathrm{HCl}$ pekat maka akan terbentuk warna merah atau ungu. Sedangkan untuk pemeriksaan senyawa steroid hasilnya negatif. Hasil uji senyawa triterpenoid ekstrak etanol $H$. durvillaei terdapat pada Gambar 2.

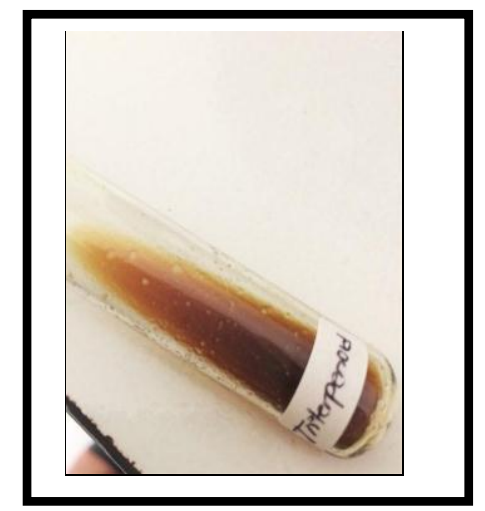

Gambar 2. Hasil pemeriksaan senyawa kualitatif Triterpenoid $H$. durvillaei

\section{Pemeriksaan Kualitatif Senyawa Tanin}

Hasil yang diperoleh dari pengujian senyawa tanin dengan menambahkan dua sampai tiga tetes Fecl3 1\% pada ekstrak dan hasil menunjukkan warna hijau sehingga ekstrak menunjukkan positif mengandung senyawa tanin. Tanin dibagi menjadi dua golongan dan masing-masing golongan memberikan reaksi warna yang berbeda terhadap
$\mathrm{FeCl}_{3} 1 \%$. Golongan tanin hidrolisis akan menghasilkan warna biru kehitaman dan tanin kondensasi akan menghasilkan warna hijau kehitaman. Pada saat penambahannya, diperkirakan $\mathrm{FeCl}_{3} \quad 1 \%$ bereaksi dengan salah satu gugus hidroksil yang ada pada senyawa tanin. Hasil reaksi tersebut yang akhirnya menimbulkan warna (A'yun \& Laily, 2015). Hasil pemeriksaan kualitatif senyawa tanin terdapat pada Gambar 3.

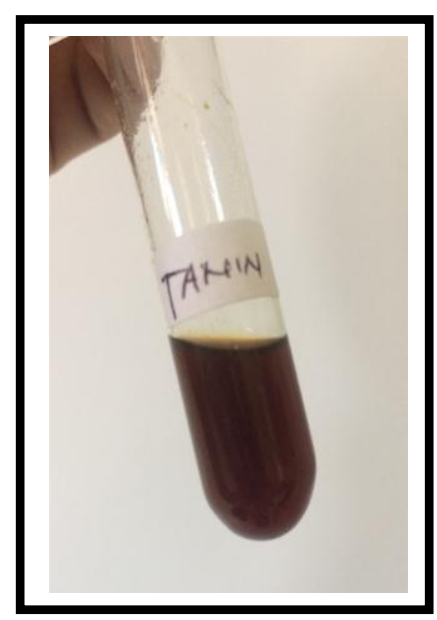

Gambar 3. Hasil pengujian senyawa kualitatif Tanin $H$. durvillaei

\section{Pemeriksaan Kualitatif Senyawa Flavonoid}

Hasil yang diperoleh dari pengujian senyawa flavonoid ekstrak ditambahkan $5 \mathrm{~mL}$ etanol kemudian dipanaskan selama 5 menit dan ditambahkan 0,29 g bubuk Mg hasil menunjukkan perubahan warna merah tua selama tiga menit sehingga ekstrak menunjukkan positif mengandung senyawa flavonoid. Menurut Sutisna (2000), ekstrak yang positif mengandung flavonoid akan berubah atau terbentuk warna merah, kuning atau jingga apabila ditetesi dengan $\mathrm{HCl}$ pekat dan ditambahkan serbuk Magnesium. Hasil uji senyawa flavonoid ekstrak etanol Halymenia durvillaei terdapat pada Gambar 4. 


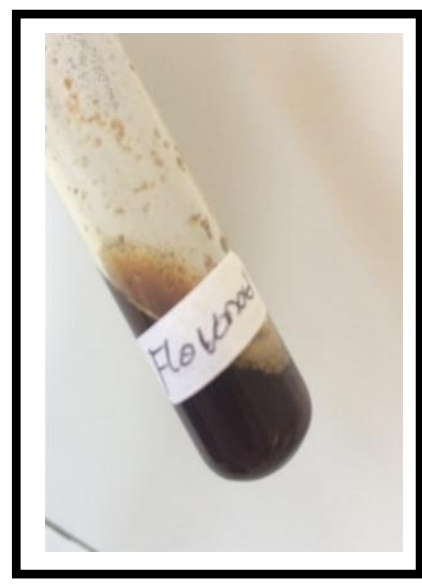

Gambar 4. Hasil pemeriksaan senyawa kualitatif Flavonoid $H$. durvillaei

\section{Pemeriksaan Kualitatif Senyawa Saponin}

Hasil yang diperoleh dari pengujian senyawa saponin ekstrak ditambahkan aquades dan dipanaskan dua sampai tiga menit kemudian didinginkan dan ditambahkan $\mathrm{NH} 3$ kemudian dikocok dan diamati busa atau buih, hasil menunjukkan ekstrak positif mengandung senyawa saponin yang ditunjukkan dengan stabilnya busa atau buih selama 1 menit lebih. Hasil uji senyawa saponin ekstrak etanol $H$. durvillaei terdapat pada Gambar 5.

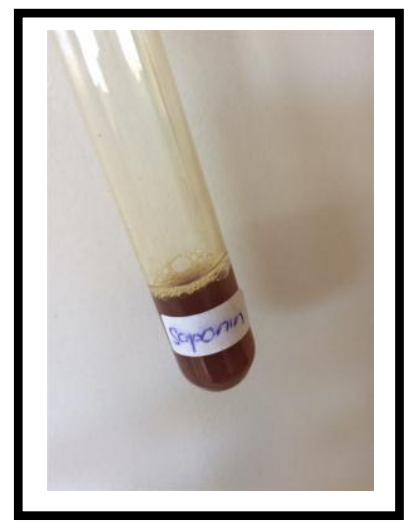

Gambar 5. Hasil uji senyawa kualitatif Saponin $H$. durvillaei

\section{KESIMPULAN}

Berdasarkan hasil penelitian skrining fitokimia dapat disimpulkan bahwa ekstrak etanol Halymenia durvillaei yang diambil dari Pesisir Pantai Desa Rendingan, Kecamatan Tabukan Kepulauan Sangihe, Sulawesi Utara mengandung senyawa bioaktif alkaloid, fenol, saponin, tanin, dan steroid.

\section{DAFTAR PUSTAKA}

A'yun Q, Ainun NL (2015) Analisis Fitokimia Daun Pepaya (Carica papaya L.) di Balai Penelitian Tanaman Aneka Kacang dan Umbi, Kendalpayak, Malang.

Darwis D (2000) Uji Kandungan Fitokimia Metabolit Sekunder. Metode Lapangan dan Laboratorium. Workshop Pengembangan Sumber Daya Manusia dalam Bidang Kimia Organik Bahan Alam Hayati. DITJEN DIKTI DEPDIKNAS, Padang.

Ditjen POM (2000) Parameter Standar Umum Ekstrak Tumbuhan Obat. Depkes, Jakarta.

Harborne JB (1987) Metode Fitokimia. Terjemahan dari Phytochemical Methods oleh Kosasih Padmawinate \& Iwang Soedino. Penerbit ITB, Bandung.

Mandal V, Yogesh MH (2007) Microwave assisted Extraction An Innovative and Promising Extraction Tool for Medicinal Plant Research. Pharmacognosy Rev 1: 7-18.

Nohong (2009) Skrining Fitokimia Tumbuhan Ophiopogon jaburan Lodd dari Kabupaten Kolaka Provinsi Sulawesi Tenggara. FMIPA, Universitas Haluoleo Kendari. Jurnal Pembelajaran Sains, 5(2): 172-178.

Robinson $\mathrm{T}$ (1991) Kandungan Organik Tumbuhan Tingkat Tinggi. Bandung: Penerbit ITB. Pp. 152-196.

Sastroamidjojo H (1996) Sintesis Bahan Alam. Yogyakarta: Gadjah Mada University Press.

Setyowati WAE, Ariani SRD, Ashadi, Mulyani B, Rahmawati CP (2014) Skrining Fitokimia dan 
27 | JURNAL BIOS LOGOS, FEBRUARI 2019, VOL. 9 NOMOR 1

Identifikasi Komponen Utama Ekstrak Metanol Kulit Durian (Durio zibethinus murr.) Varietas Petruk. Seminar Nasional Kimia dan Pendidikan Kimia VI. Prodi Pendidikan Kimia Jurusan FMIPA FKIP Universitas Surakarta.
Sutisna I (2000) Isolasi dan Karakterisasi Senyawa Triterpenoid Lanostana daari Kulit Kayu Danglo (Macaranga javanica Muell. Arg). [SKRIPSI] Jurusan Kimia FMIPA. Institut Pertanian Bogor.

